\title{
Amateur Genealogy in the Present-Day Poland: An Anthropological Approach
}

\author{
Marta Raczyńska-Kruk \\ Jagiellonian University in Cracow, \\ Department of History, Institute of Ethnology and Cultural Anthropology
}

\begin{abstract}
Since antiquity, genealogy was practiced mainly in the noble families. It has been treated as a tool of legitimization of social and political range. People often used to refer to mythical origins of a family as an imaginary sphere of references to the common past. This paper concerns the idea of amateur genealogy in the present-day Poland and societies of Polish roots. The overall objective is that increasing interest in the search of ancestors is related to specific "fashion" and the need for people's own place in the so-called 'Great History'. From the perspective of cultural anthropology, the amateur genealogy responses to the identity crisis in the contemporary world and the process of democratization of the collective memory. In Poland, this phenomenon took a significant form, resulting from the history of the Polish nation and still actual problems with social identification: resentment towards the noble past and, very often, the need for having gentry roots. On the other hand, more and more Poles decided to discover their family past and give a voice to their ancestors who were excluded from the traditional historiography: peasants, craftsmen, burghers etc. The first results of ethnographic research (carried out by using classical methods: interviews, participating observation, etc. as well as the virtual-ethnography) show that in Poland, amateur genealogy seems to be the mirror of Polish identity and the mythologized history. What is more, it is also a phenomenon reflecting universal mechanisms of family memory as a unique system of narrations.
\end{abstract}

Keywords: memory; family; ethnography; genealogy; ancestors. 